\title{
Kronik Hemodiyalizli Olguların Ayaklarında Periferik Nöropatinin Araştırılması
}

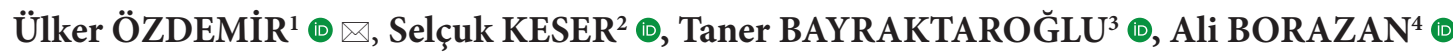 \\ ${ }^{1}$ Zonguldak Bülent Ecevit Üniversitesi, Sağlık Bilimleri Enstitüsü, Podoloji Yüksek Lisansı, Zonguldak, Türkiye \\ ${ }^{2}$ Zonguldak Bülent Ecevit Üniversitesi, Tip Fakültesi, Ortopedi ve Travmatoloji Anabilim Dalı, Zonguldak, Türkiye \\ ${ }^{3}$ Zonguldak Bülent Ecevit Üniversitesi, Tip Fakültesi, Endokrinoloji ve Metabolizma Hastalıkları Bilim Dalı, Zonguldak, Türkiye \\ ${ }^{4}$ Zonguldak Bülent Ecevit Üniversitesi, Tip Fakültesi, Nefroloji Bilim Dalı, Zonguldak, Türkiye
}

Bu makaleye yapılacak atıf: Özdemir Ü, Keser S, Bayraktaroğlu T, Borazan A. Kronik Hemodiyalizli Olguların Ayaklarında Periferik Nöropatinin Araștırılması. Türk Diyab Obez 2020;2: 119-129.

\begin{abstract}
ÖZ
Amaç: Çalışmamızda son dönem böbrek hastalığı nedeniyle hemodiyalize giren hastaların ayaklarında nöropatinin araştırılması amaçlandı.

Gereç ve Yöntemler: Çalışmaya diabetes mellitus (DM) tanısı olmayan 35 hemodiyaliz hastası (Grup-I), DM tanılı 26 hemodiyaliz hastası (Grup-II), kronik böbrek hastalığı olmayan Tip 2 DM tanılı 50 hastadan (Grup-III) oluşan toplam 111 hasta alındı. Nöropati tespitinde subjektif semptom varlı̆̆ı, Semmes Weinstein monofilament incelemesi, diyapazon ve biyoteziyometrede vibrasyon algılama eşikleri ile aşil refleksinin varlığı kullanıldı. Gruplarda saptanan veriler analiz edildi.

Bulgular: Grup-I'deki hemodiyaliz olguların \%17,0'sinde nöropati tespit edilirken, Grup-II'deki DM tanılı hemodiyaliz olguların \%69,0'unda, Grup-III' deki DM tanılı olguların \%24,0'ünde nöropati tespit edildi. Grup II'deki nöropati oranı Grup-I ve Grup-III'e göre anlamlı yüksek bulundu ( $<<0,001)$. Grup-I ve Grup-III arasında anlamlı fark bulunmadı $(\mathrm{p}>0,05)$.

Sonuç: Hemodiyaliz hastalarında Diabetes Mellitus olmasa da nöropati sık görülmektedir. Bundan dolayı hemodiyalize giren hastalara düzenli podolojik ayak muayenesinin yapılmasının ve nöropati açısından değerlendirilmesinin uygun olacağını düşünmekteyiz.

Anahtar Sözcükler: Nöropati, Diyabetik periferik nöropati, Diabetes mellitus, Kronik böbrek hastalı̆̆ı, Hemodiyaliz
\end{abstract}

\section{Evaluation of Peripheral Neuropathy in the Feet of the Cases with Chronic Hemodialysis}

\begin{abstract}
Aim: In this study, we aimed to evaluation peripheral neuropathy in the feet of the cases with chronic hemodialysis.

Material and Methods: The study included in 111 hemodialysis patients. (Group-I) 35 hemodialysis patients without diabetes mellitus, (Group-II) 26 hemodialysis patients with diabetes mellitus, and (Group-III) 50 patients with type 2 diabetes mellitus without chronic kidney disease. The diagnostic criteria that, presence of subjective symptoms, Semmes Weinstein monofilament examination, vibration detection thresholds with diapasone and biotesiometer, and presence of achilles reflex, used in the diagnosis of neuropathy were recorded in the data collection form.

Results: Neuropathy percentages were detected $17.0 \%$ in Group-I cases with hemodialysis, $69.0 \%$ in Group-II cases with diabetes mellitus and hemodialysis, and $24.0 \%$ in Group-III cases with type 2 diabetes mellitus without chronic kidney diseases. The rate of neuropathy in Group II was significantly higher than Group-I and Group-III ( $\mathrm{p}<0.001)$. There were no significant differences acording to neuropathy percentages between Group-I and Group-III ( $p>0.05$ ).

Conclusion: Neuropathy is seen frequently in hemodialysis patients without diabetes mellitus, we think that regular podological foot examination and evaluation of neuropathy should be done for hemodialysis patients.
\end{abstract}

Key Words: Neuropathy, Diabetic peripheral neuropathy, Diabetes mellitus, Chronic kidney diseases, Hemodialysis

ORCID: Ülker Özdemir / 0000-0002-5332-3423, Selçuk Keser / 0000-0002-5595-590X, Taner Bayraktaroğlu / 0000-0003-3159-6663, Ali Borazan / 0000-0003-0980-8690 


\section{GİRIS}

Kronik böbrek hastalığı (KBH), böbrek fonksiyonlarında ya da glomerüler filtrasyon hızında azalma sonucu vücutta üremik toksinlerin birikmesi, sıvi-solüt ve asit-baz dengesinin bozulması, metabolik ve endokrin fonksiyonlarında ilerleyici bozulma hâli olarak tanımlanmaktadır (1). Diabetes Mellitus (DM) hastalığının oldukça önemli bir komplikasyonudur. Gerek DM, gerekse KBH ise pek çok nörolojik komplikasyona neden olabilmektedir (2).

Diyabetik periferik nöropati (DPN) her zaman klinik olarak belirgin değildir ve olguların çoğunda subkliniktir (3). Bu nedenle, hekimin izlemler sirasinda sadece subjektif semptomlara dikkat etmesi durumunda DPN'nin saptanması kaçınılmaz olarak gecikecek ve bu şekilde tedavi ve prognoz etkilenecektir. DPN’nin saptanması açısından yüksek başarı oranı ile sinir ileti testlerinin incelenmesi kesin olarak etkili bir yaklaşımdır (4). Buna karşıllı, zaman gerektirmesi ve pahalı olması, poliklinikte izlenen hastalarda DPN taraması açısından çoğu hekim bu yaklaşımı uygun bulmamaktadır (5). Bu nedenle, kısıtlı bir zaman içinde gerçekleştirilebilen çok sayıda alternatif kantitatif duysal test (KDT) protokolü öne sürülmüş ve etkinlikleri bildirilmiştir (6-8). Semmes-Weinstein monofilament incelemesi (SWMI) diyabetik ayakta koruyucu duyu kaybının saptanması amacı ile kullanılmaktadır (9-11). Son zamanlarda bu yöntem, DPN taraması için kullanılması amacı ile diğer KDT protokolleri ile birlikte ya da daha ince kalibreli diğer filamentler kullanılarak test edilmektedir (12-14).

Sağlık alanında ayak hastalıkları üzerine podolojik tedavi ve bakım hizmeti, hemodiyalize giren hastaların değişik yöntemlerle değerlendirilmesini gündeme getirmiştir. Bunun yanında üremik periferik nöropati açısından da değerlendirildiğinde kaliteli bakım almış olacak ve komplikasyonlardan zarar görme olasılı̆̆ını en aza indirecektir.

Kronik böbrek hastalığına bağlı ayakta görülen nöropati hasta tarafından zor fark edilmekte ancak dikkatli klinik değerlendirmeyle ortaya çıkarılabilmektedir. Bu çalışmada kronik böbrek hastalığı nedeni ile diyabeti olan ve olmayan hemodiyaliz hastalarının ayaklarında nöropati prevelansı değerlendirilmesi amaçlandi. Subjektif semptomlar, monofilament duyu testi, diyapazon, biyoteziyometre cihazı ve aşil refleksi ve ilişkili demografik, klinik ve laboratuvar parametreleri tespit edilerek analizler yapıldı.

\section{GEREÇ ve YÖNTEMLER}

Araştırmamız Zonguldak Bülent Ecevit Üniversitesi (ZBEÜ) Sağlık Uygulama ve Araştırma Merkezi Zonguldak Atatürk Devlet Hastanesi'nin hemodiyaliz üniteleri ile ZBEÜ Obezite ve Diyabet Uygulama ve Araştırma Merkezi Podoloji
Ünitesi'nde gerekli izinler alındıktan sonra gerçekleştirildi. Zonguldak Bülent Ecevit Üniversitesi Klinik Araştırmalar Etik Kurulu'ndan onay alındı (03.04.2019 tarihli ve 2019/05 Karar No). Araştırmayı kabul eden hastaların kendisinden ya da yakınlarından yapılacak araştırma hakkında gerekli açıklama yapılarak sözlü ve yazılı bilgilendirilmiş onamları alındi.

Araştırmaya dâhil edilecek kişi sayısı tek yönlü varyans analizi için 0,3 etki büyüklüğü, $\alpha=0.05$ ve $\% 80$ güç için çalışmaya alınması gereken minimum örneklem sayısı 111 olarak hesaplandı. Bu hesaplama G-Power 3.1.9.2 paket programı kullanılarak yapıldı. Araştırmaya alınma kriterlerini 18 yaşından büyük olma, üç aydan daha uzun süre hemodiyalize giriyor olma, ayak ülseri ve amputasyonu bulunmaması, hemodiyaliz tedavisi almayı Tip 2 DM tanısı olanlar oluşturmaktaydı. Sağlık Uygulama ve Araştırma Merkezi hemodiyaliz ünitesinde 38 olgudan 33 olgu dâhil edildi. Olgulardan biri çalışmaya katılmayı kabul etmedi. Sol ayak ampütasyonlu iki olgu ve sağ ayak başparmak diyabetik ayak yarası bulunan iki olgu çalışmaya alınmadı. Zonguldak Atatürk Devlet Hastanesi hemodiyaliz ünitesinde 70 olgudan 28 olgu araştırmaya dâhil edildi. Ayak amputasyonu olanlar, ayak ülserasyonu olanlar, çalışmaya katılmayı kabul etmeyenler çalışmadan dışlandı. Yeterli örneklem sayısına ulaşılınca çalışma tamamlandı. Obezite ve Diyabet Uygulama ve Araştırma Merkezi Podoloji Ünitesi'nde Tip 2 Diabetes Mellitus tanısı ile takip edilen 50 olgu araştırmaya dâhil edildi.

Gönüllü olmayan, 18 yaş altı olgular, hemodiyaliz süresi üç ayın altında olanlar, ayak ülserasyonu olan ve amputasyonu geçirenler örneklem dışı bırakıldı.

Çalışmaya alınan olgular üç gruba ayrıldı. Grup-I diabetes mellitus tanısı olmayan hemodiyaliz hastalarından, GrupII diabetes mellitus tanılı hemodiyaliz hastalarından ve Grup-III Kronik böbrek hastalığı olmayan ve Tip 2 diabetes mellitus tanılı hastalardan oluşturuldu.

Veriler olgu rapor formu ile topland1. Olgu rapor formunun;

1. bölümünü olguya ait demografik verileri; yaş, cinsiyetin,

2. bölümünü olguya ait klinik bilgileri; boy, kilo, vücut kütle indeksi(VKİ), kan basıncının,

- 3. bölümünü olguya ait laboratuvar değerleri; serum üre, kreatinin, açlık kan şekeri, sodyum, potasyum, kalsiyum, fosfor, parathormon, vitamin B12, folik asit, $\mathrm{HbA1C}$ değerlerinin,

- Dördüncü bölümünü kronik böbrek hastalığının etiyolojisi, hemodiyaliz süresi, diabetes mellitus etiyolojisinin, 
- 5. bölümünü; nöropati bulgularını subjektif değerlendirilmesi; ellerde ağrı, ayaklarda ağrı sorgulanması, ekstremitelerde uyuşukluk, her iki ayakta parestezi, ekstremitelerde soğukluk duyusu, ekstremitelerde yanma duyusu, kabızlık, ishal, kas krampları, güçsüzlük, bas dönmesi, idrar yapmada güçlük, ayaklarda ülser ya da tırnaklarda renk değişikliğinin sorgulanmasının;

- 6. bölümünü; Semmes weinstein (5.07) 10 g monofilament testinin;

- 7. bölümünü; diyapazon testi; sekizinci bölümünü; biyoteziyometre testi ile değerlendirme; dokuzuncu bölümünü ise aşil refleksi bulgularının refleks çekici ile değerlendirilmesinin

kayıt edildiği çizelge oluşturmaktaydı.

Grup-I, Grup-II, Grup-III olgularının ayaklarında nöropati değerlendirilmesi yapılırken kullanılan teknik donanıma ilişkin özellikler aşağıda belirtilmektedir.

Semmes-Weinstein monofilamenti testi 10 gr (5.07) standart monofilament (Diabetic foot care India Pvt limited) ile yapild1.

Diyapazon testi: marka $128 \mathrm{~Hz}$ diyapazon (RIESTER CE) ile yapıldı.

Biyoteziyometre testi: Vibrotest digital biothesiometer marka cihaz kullanılarak yapıldı.

Aşil refleksi: Olgular yatarken veya otururken refleks çekici ile aşil refleksinin olup olmadığ değerlendirildi.

Nöropati tanısı: Periferik nöropatinin kabul edilen tanı kriterleri olan;

1. Subjektif semptomlar, (a) ayaklarda ağrı; (b) ekstremitelerde uyuşukluk; (c) her iki ayakta parestezi semptomları olgularda "yok" ya da "var" olarak değerlendirildi.

2. Semmes-Weinstein monofilament incelemesi (SWMİ); ayak tabanında 4 noktaya uygulanan SWMİ'nin en az birinde hissedilmemesi duyu kaybı var olarak değerlendirildi.

3. Alt ekstremitelerin vibrasyon algılama eşikleri (VAE)

a. Diyapazon testi: Diyapazonun titreșimini 10 saniyeden daha uzun sürede hissedenlerde vibrasyon duyusu var, 10sn'den daha kısa sürede hissedenlerde vibrasyon duyusu yok olarak değerlendirildi.

b. Biyoteziyometre testi: Titreşimi 25 Volt üzerinde hissedenler duyu kaybı var, 25 Volt altı hissedenler duyu kaybı yok olarak değerlendirildi.

4. Aşil refleksi: Aşil refleksi var veya yok olarak değerlendirildi.
Nöropati tanısı için yukarıda sayılan kriterlerden 2 veya daha fazlasının sağlanması durumunda nöropatinin var olduğu kabul edildi.

$\mathrm{Bu}$ araştırmada olguların takip dosyalarından olguların yaş, cinsiyet, boy, kilo, vücut kütle indeksi (VKİ) gibi demografik verileri ile hemodiyaliz süresi, kronik böbrek hastalığının etiyolojisi, kan basıncı, serum üre, kreatinin, açlık kan şekeri, sodyum, potasyum, kalsiyum, fosfor, parathormon, vitamin $\mathrm{B} 12$, folik asit, $\mathrm{HbA1C}$ değerleri kaydedildi. Ayaklarda nöropatinin değerlendirilmesi için hazırlanan olgu formuna göre olguların ayaklarında nöropatinin klinik değerlendirilmesi yapıldı. Nöropatinin tespitinde ilk test olarak Semmes-Weinstein monofilamenti testi ile ayak tabanında dört standart bölgeye (birinci, üçüncü ve beşinci metatars başları ve distalhalluksun plantar tarafi) bakıldı. Bu bölgelerde test sırasında 10 gr'lık $(5,07)$ filamentin hissedilmemesi patolojik olarak kabul edildi. İkinci testimiz olan titreşim çatalı da denilen diyapazon $(128 \mathrm{hz})$ ile vibrasyon duyusu değerlendirildi. Her iki ektremitenin başparmağ üzerinde uygulandı. Titreşimi hissetme süresi kaydedildi. 10 saniyenin üzerinde hissederse vibrasyon duyusu var kabul edildi. Üçüncü testimiz ise nöropatiyi objektif değerlendiren biyoteziyometre ile yapıldı. Biyoteziyometre 0-50 volt arasında değer gösterir. Artan şiddette titreşim gönderilerek ölçüm yapılarak olgunun titreşimi hissettiği nokta vibrasyon eşiği olarak kabul edildi. 25 volt üzeri hissedenler nöropati olarak değerlendirildi. Ayrıca olguların bilateral aşil refleksi olup olmadığına bakıldı. Bulgular her olgu için ayrı ayrı hazırlanan olgu rapor formuna kaydedildi.

\section{İstatistiksel Analiz}

Yapılan araştırma sonrası elde edilen verilerin istatistiksel analizleri SPSS 19.0 (SPSS Inc., Chicago, IL, ABD) programı kullanılarak analiz edildi. Çalışmada yer alan sürekli değişkenlere ait tanımlayıcı istatistikler ortalama, standart sapma, medyan, minimum ve maksimum değerleriyle; kategorik değişkenler frekans ve yüzde ile gösterildi. Sürekli değişkenlerin normal dağılıma uygunluğu Shapiro Wilk testi ile incelendi. Normal dağılım göstermeyen değişkenlerin iki grup karşılaştırılmalarında Mann Whitney-U testi, 3 ve daha fazla grup karşılaştırmalarında Kruskal Wallis testi, 2'li alt grup karşılaştırmalarında Bonferonni düzeltmeli Mann Whitney U testi kullanıldı. Nitel değişkenlerin gruplar arası karşılaştırmalarında Pearson ki-kare testi kullanıldı. Çalışmadaki tüm istatistiksel analizlerde p değeri 0,05 'in altındaki sonuçlar istatistiksel olarak anlamlı kabul edildi.

\section{BULGULAR}

Çalışmaya alınan olguların gruplardaki dağılımına bakıldığında toplamda 111 olgu dâhil edildi. Bu olguların \%51'i kadın, \%49'u erkek idi. Grup-I içinde DM tanısı 
olmayan 35 hemodiyaliz olgusu (13 kadın, 22 erkek), GrupII'de DM tanısı olan 26 hemodiyaliz olgusu (14 kadın, 12 erkek), Grup-III'te kronik böbrek hastalığı olmayan 50 Tip 2 DM tanılı olgu (30 kadın, 20 erkek) mevcuttu. Grup-I'in \%37'si kadın ve \%63'ü erkek, Grup-II'nin \%54'ü kadın ve \%46'sı erkek, Grup-III'ün ise \%60'ı kadın ve $\% 40$ 'ı erkek olgulardan oluşmaktaydı. Grup-I hemodiyaliz olgularının kronik böbrek hastalığı etiyolojileri Tablo 1'de gösterilmiştir. Etiyolojilerin çoğunluğunu hipertansiyon ve glomerulonefrit oluşturmaktaydı (Tablo 1).

Çalışma gruplarının demografik verileri; yaş, cinsiyet ve vücut kütle indeksi (VKI); klinik özellikleri; hemodiyaliz
Tablo 1: Grup-I hemodiyalize giren olgularda kronik böbrek hastalığının etiyolojileri.

\begin{tabular}{lc}
\hline KBH Etiyolojisi & Olgu Sayısı n (\%) \\
\hline Hipertansiyon & $10(28,6)$ \\
Glomerülonefrit & $9(25,7)$ \\
Kistik Böbrek Hastalığı & $7(20)$ \\
Ürolojik Hastalıklar & $5(14,3)$ \\
Nedeni Bilinmeyenler & $3(8,6)$ \\
Amiloidosis & $1(2,8)$ \\
\hline Toplam & $35(100)$
\end{tabular}

n: sayı, \%: yüzde

Tablo 2: Çalışma gruplarının demografik ve laboratuvar sonuçları ile istatistiksel analizleri.

\begin{tabular}{|c|c|c|c|c|c|c|}
\hline $\begin{array}{l}\text { Laboratuvar, Demografik, } \\
\text { Klinik ve Tanı Kriterleri }\end{array}$ & $\begin{array}{l}\text { Grup-I } \\
(\mathrm{n}=35)\end{array}$ & $\begin{array}{c}\text { Grup-II } \\
(n=26)\end{array}$ & $\begin{array}{c}\text { Grup-III } \\
(n=50)\end{array}$ & $\begin{array}{c}\mathrm{I}-\mathrm{II} \\
p\end{array}$ & $\begin{array}{c}\mathrm{I}-\mathrm{III} \\
p\end{array}$ & $\begin{array}{l}\text { II-III } \\
p\end{array}$ \\
\hline $\begin{array}{l}\text { Yaş (yıl } \pm S S) \\
\text { Med. (Min.-Mak) }\end{array}$ & $\begin{array}{l}59,6 \pm 13,8 \\
61(29-85)\end{array}$ & $\begin{array}{c}66,9 \pm 9,3 \\
67(48-88)\end{array}$ & $\begin{array}{c}56,6 \pm 8,2 \\
57(38-7457)\end{array}$ & 0,760 & 0,240 & 0,122 \\
\hline Cinsiyet(K/E) & $13 / 22$ & $14 / 12$ & $30 / 20$ & - & - & - \\
\hline $\begin{array}{l}\text { VKİ }\left(\mathrm{kg} / \mathrm{m}^{2} \pm \mathrm{SS}\right) \\
\text { Med. (Min.-Mak) }\end{array}$ & $\begin{array}{c}24,8 \pm 5,6 \\
23,7(14,5-44,9)\end{array}$ & $\begin{array}{c}27,4 \pm 6,4 \\
27,5(18,4-4,4)\end{array}$ & $\begin{array}{c}30,8 \pm 5,0 \\
29,7(22,2-45,34)\end{array}$ & 0,310 & 0,019 & 0,253 \\
\hline $\begin{array}{l}\text { Hemodiyaliz Süresi }(\mathrm{Ay} \pm \mathrm{SS}) \\
\text { Med. (Min.-Mak) }\end{array}$ & $\begin{array}{l}53,9 \pm 36,6 \\
48(5-160)\end{array}$ & $\begin{array}{c}42 \pm 33,9 \\
34(6-142)\end{array}$ & - & 0,160 & - & - \\
\hline Hipertansiyon $[\mathrm{n}(\%)]$ & $32(\% 91,4)$ & $23(\% 88,5)$ & $34(\% 68)$ & 0,560 & 0,300 & 0,329 \\
\hline $\begin{array}{l}\text { Üre }(\mathrm{mg} / \mathrm{dl} \pm \mathrm{SS}) \\
\text { Med. (Min.-Mak) }\end{array}$ & $\begin{array}{c}127,8 \pm 31,14 \\
125,6(63-194,7)\end{array}$ & $\begin{array}{c}117,4 \pm 21,2 \\
118,5(79-167)\end{array}$ & $\begin{array}{c}28,6 \pm 7,8 \\
28(13-48)\end{array}$ & 0,160 & 0,001 & 0,001 \\
\hline $\begin{array}{l}\text { Kreatinin }(\mathrm{mg} / \mathrm{dl} \pm \mathrm{SS}) \\
\text { Med. (Min.-Mak) }\end{array}$ & $\begin{array}{c}7,79 \pm 2,34 \\
7,6(3,7-13,9)\end{array}$ & $\begin{array}{c}5,88 \pm 1,6 \\
5,7(2,6-9,8)\end{array}$ & $\begin{array}{c}0,83 \pm 0,1 \\
0,8(0,6-1)\end{array}$ & 0,300 & 0,001 & 0,001 \\
\hline $\begin{array}{l}\text { AKŞ (mg/dlıSS) } \\
\text { Med. (Min.-Mak) }\end{array}$ & $\begin{array}{c}89,8 \pm 8,35 \\
89(73-106)\end{array}$ & $\begin{array}{c}182,1 \pm 81,1 \\
153(94-380)\end{array}$ & $\begin{array}{c}131,5 \pm 32,1 \\
125(104-273)\end{array}$ & 0,001 & 0,001 & 0,253 \\
\hline $\begin{array}{l}\text { Sodyum }(\mathrm{mg} / \mathrm{dl} \pm \mathrm{SS}) \\
\text { Med. (Min.-Mak) }\end{array}$ & $\begin{array}{c}139,0 \pm 2,5 \\
139(134-145)\end{array}$ & $\begin{array}{c}138,6 \pm 2,9 \\
139(132-143)\end{array}$ & $\begin{array}{c}141,4 \pm 2,5 \\
142(138-145)\end{array}$ & 0,177 & 0,860 & 0,005 \\
\hline $\begin{array}{l}\text { Potasyum }(\mathrm{mg} / \mathrm{dl} \pm \mathrm{SS}) \\
\text { Med. (Min.-Mak) }\end{array}$ & $\begin{array}{c}5,21 \pm 0,5 \\
5,2(3,8-6,3)\end{array}$ & $\begin{array}{c}4,9 \pm 0,6 \\
5(3,7-6,2)\end{array}$ & $\begin{array}{c}4,4 \pm 0,3 \\
4,4(3,7-5)\end{array}$ & 0,120 & 0,002 & 0,006 \\
\hline $\begin{array}{l}\text { Kalsiyum }(\mathrm{mg} / \mathrm{dl} \pm \mathrm{SS}) \\
\text { Med. (Min.-Mak) }\end{array}$ & $\begin{array}{c}8,79 \pm 0,7 \\
8,9(6,5-10,1)\end{array}$ & $\begin{array}{c}8,87 \pm 0,4 \\
8,9(8,4-9,9)\end{array}$ & $\begin{array}{c}9,7 \pm 0,5 \\
9,7(8,7-10,7)\end{array}$ & 0,710 & 0,002 & 0,001 \\
\hline $\begin{array}{l}\text { Fosfor }(\mathrm{mg} / \mathrm{dl} \pm \mathrm{SS}) \\
\text { Med. (Min.-Mak) }\end{array}$ & $\begin{array}{c}4,85 \pm 1,3 \\
5(1,8-7,8) \\
\end{array}$ & $\begin{array}{c}4,55 \pm 0,9 \\
4,6(3-6,7)\end{array}$ & $\begin{array}{c}3,74 \pm 0,4 \\
3,7(2,9-4,5)\end{array}$ & 0,360 & 0,066 & 0,288 \\
\hline $\begin{array}{l}\text { Parathormon (pg/ml } \pm S S \text { ) } \\
\text { Med. (Min.-Mak) }\end{array}$ & $\begin{array}{c}456,3 \pm 408 \\
316,8(68,2-1914)\end{array}$ & $\begin{array}{c}313,3 \pm 524 \\
183,5(62,1-2801)\end{array}$ & $\begin{array}{c}29,8 \pm 11,5 \\
26,5(17-68,8)\end{array}$ & 0,640 & 0,001 & 0,001 \\
\hline $\begin{array}{l}\text { Vitamin-B12 (pg/ml } \pm S S) \\
\text { Med. (Min.-Mak) }\end{array}$ & $\begin{array}{c}1165,9 \pm 741 \\
982(146-2000)\end{array}$ & $\begin{array}{c}725,7 \pm 706 \\
294(133-2000)\end{array}$ & $\begin{array}{c}334,3 \pm 215 \\
282,5(123-1232)\end{array}$ & 0,060 & 0,011 & 0,267 \\
\hline $\begin{array}{l}\text { Folat (ng/ml } \pm \text { SS) } \\
\text { Med. (Min.-Mak) }\end{array}$ & $\begin{array}{c}12,6 \pm 7,7 \\
12(1,6-24)\end{array}$ & $\begin{array}{c}12,2 \pm 6,3 \\
12(3,4-25)\end{array}$ & $\begin{array}{c}9,9 \pm 5,6 \\
8,9(3-25)\end{array}$ & 0,740 & 0,810 & 0,287 \\
\hline $\begin{array}{l}\text { HbA1C (\% } \pm S S) \\
\text { Med. (Min.-Mak) }\end{array}$ & $\begin{array}{l}- \\
-\end{array}$ & $\begin{array}{c}7,11 \pm 1,4 \\
6,75(5,4-12)\end{array}$ & $\begin{array}{c}7,19 \pm 1,7 \\
6,35(5,1-10,9)\end{array}$ & - & 0,181 & 0,582 \\
\hline
\end{tabular}

VKİ; Vücut Kütle İndeksi, AKŞ; Açlık Kan Şekeri, SS: Standard sapma, HbAlc; glikolize hemoglobin, Med. (Min.-Mak); Medyan (Minimum-Maksimum) 
(HD) süresi ve hipertansiyon (HT) varlığ1; serum üre, kreatinin, açlık kan şekeri (AKŞ), sodyum $(\mathrm{Na})$, potasyum $(\mathrm{K})$, kalsiyum $(\mathrm{Ca})$, fosfor $(\mathrm{P})$, parathormon $(\mathrm{PTH})$, vitamin B12 (Vit-B12), folik asit (folat) ve HbA1C laboratuvar değerleri ile istatistiksel değerlendirme sonuçları Tablo 2'de gösterilmiştir.

Grup-I'deki olguların yaş ortalaması $59,6 \pm 13,8$ yıl; Grup-II'deki olguların yaş ortalaması $66,9 \pm 9,3$ yıl; Grup-III'deki olguların yaş ortalaması 56,6 $\pm 8,2$ yll olarak bulundu. Grup-I'deki kadın-erkek olguların sayısı 13-22; Grup-II'deki kadın-erkekolguların sayısı 14-12;Grup-III'deki kadın-erkek olguların sayısı 30-20 olarak bulundu. Vücut kütle indekslerine bakıldığında Grup-I'in ortalama değeri $24,8 \pm 5,6 \mathrm{~kg} / \mathrm{m}^{2}$; Grup-II'nin ortalama değeri $27,4 \pm 6,4 \mathrm{~kg} /$ $\mathrm{m}^{2}$; Grup-III'ün ortalama değeri $30,8 \pm 5,0 \mathrm{~kg} / \mathrm{m}^{2}$ olarak bulundu. Gruplar arası ortalama yaş ve cinsiyet sonuçlarının istatistiksel karşılaştırılmasında olarak anlamlı bir fark bulunmadı ( $p>0,05)$. Ortalama VKİ’nin karşılaştırılmasında Grup-I ile Grup-II arasında ve Grup-II ile Grup-III arasın- da istatistiksel olarak anlamlı bir fark bulunmadı $(p>0,05)$. Grup-I ile Grup-III arasındaki ortalama VKİ karşılaştırıld1ğında istatistiksel olarak Grup-I'deki ortalama VKİ anlamlı olarak düşük bulundu $\mathrm{p}=0.019)$. Ancak Bonferoni düzeltmesine göre grup karşılaştırmasında anlamlılık sınırı 0,016 değerinden büyük olduğundan düşüklük anlamlı kabul edilmedi. Hemodiyaliz süresi ve hipertansiyon varlığına bakıldığında gruplar arasında istatistiksel olarak anlamlı fark bulunmadi ( $\mathrm{p}>0,05)$ (Tablo 2).

Grup-I ile Grup-II arasında laboratuvar bulguları arasında ortalama açlık kan şekeri dışındaki değerlerde istatistiksel olarak anlamlı fark bulunmadı ( $\mathrm{p}>0,05)$. Grup II'deki açlık kan şekeri yüksekliği istatistiksel olarak anlamlı bulundu $(p<0,001)$. Grup-I ile Grup-III arasında üre, keratinin, potasyum, parathormon ve Vitamin-B12 ortalama değerleri Grup-I'de istatistiksel olarak anlamlı bulundu $(\mathrm{p}<0,001)$. Grup-I'de kalsiyum ortalama değerleri anlamlı olarak düşük bulundu $(\mathrm{p}<0,05)$. Grup-II ile Grup-III arasında Grup-II'de üre, keratinin, potasyum ve parathormon

Tablo 3: Grup-I'e ait demografik, klinik verilerin, laboratuvar ortalamaları ve nöropati tanı kriterlerinin sayı (oranı) ile istatistiksel değerlendirme sonuçları.

\begin{tabular}{|c|c|c|c|}
\hline \multirow{2}{*}{ Demografik, Klinik, Laboratuvar ve Tanı Kriterleri } & \multicolumn{2}{|c|}{ Grup-I } & \multirow{2}{*}{$p$} \\
\hline & Nöropati var $(n=6)$ & Nöropati yok $(n=29)$ & \\
\hline Yaş (yıl $\pm S S$ ) & $66,8 \pm 12,5$ & $58,1 \pm 13,8$ & 0,142 \\
\hline Cinsiyet (K/E) & $2 / 4$ & $11 / 18$ & 0,834 \\
\hline Vücut kütle indeksi $\left(\mathrm{kg} / \mathrm{m}^{2} \pm \mathrm{SS}\right)$ & $25,5 \pm 3,9$ & $24,6 \pm 5,9$ & 0,381 \\
\hline Hipertansiyon $[\mathrm{n}(\%)]$ & $6(100)$ & $26(90)$ & 0,417 \\
\hline Hemodiyaliz Süresi $(\mathrm{Ay} \pm \mathrm{SS})$ & $66,5 \pm 47,4$ & $51,3 \pm 34,5$ & 0,470 \\
\hline Üre $(\mathrm{mg} / \mathrm{dl} \pm \mathrm{SS})$ & $133,1 \pm 27,5$ & $126,6 \pm 32,1$ & 0,599 \\
\hline Kreatinin $(\mathrm{mg} / \mathrm{dl} \pm \mathrm{SS})$ & $6,6 \pm 1,9$ & $8,03 \pm 2,3$ & 0,182 \\
\hline Açlık kan şekeri (mg/dl $\pm S S)$ & $89,33 \pm 8,4$ & $89,96 \pm 8,4$ & 0,869 \\
\hline Sodyum $(\mathrm{mg} / \mathrm{dl} \pm \mathrm{SS})$ & $139,50 \pm 1,0$ & $138,93 \pm 2,7$ & 0,479 \\
\hline Potasyum $(\mathrm{mg} / \mathrm{dl} \pm \mathrm{SS})$ & $5,3 \pm 0,4$ & $5,18 \pm 0,5$ & 0,430 \\
\hline Kalsiyum (mg/dl $\pm \mathrm{SS})$ & $8,6 \pm 0,5$ & $8,8 \pm 0,7$ & 0,292 \\
\hline Fosfor $(\mathrm{mg} / \mathrm{dl} \pm \mathrm{SS})$ & $4,8 \pm 0,9$ & $4,8 \pm 1,3$ & 0,930 \\
\hline Parathormon $(\mathrm{pg} / \mathrm{ml} \pm \mathrm{SS})$ & $335,6 \pm 283$ & $481,3 \pm 429,1$ & 0,381 \\
\hline Vitamin-B12 (pg/ml) & $1705,33 \pm 721,8$ & $1046,11 \pm 703,2$ & 0,083 \\
\hline Folat $(\mathrm{ng} / \mathrm{ml} \pm \mathrm{SS})$ & $12,5 \pm 8,2$ & $12,6 \pm 7,7$ & 0,961 \\
\hline Subjektif semptom var [n(\%)] & $6(100)$ & $7(24,0)$ & 0,041 \\
\hline SWMİ ile duyu kaybı var [n(\%)] & $5(83,0)$ & $3(10,0)$ & 0,001 \\
\hline Diyapazon duyu yok [n(\%)] & $6(100)$ & $5(17,0)$ & 0,001 \\
\hline Biyoteziyometri duyu yok [n(\%)] & $5(83,0)$ & $1(3,0)$ & 0,001 \\
\hline Aşil refleksi yok [n(\%)] & $0(0)$ & $0(0)$ & \\
\hline
\end{tabular}

*Semmes Weinstein monofilament incelemesi 
yüksekliği anlamlı bulundu $(\mathrm{p}<0,05)$ ve kalsiyum düşüklüğü $(\mathrm{p}<0,001)$. Bununla birlikte kalsiyum oranları Grup-I'de anlamlı düşüktü (Tablo 2).

Grup-I'de nöropati tespit edilen olguların yaş ortalamasının $66,8 \pm 12,5$ yll, nöropati tespit edilmeyen olguların yaş ortalamasının 58,1 $\pm 13,8$ yıl olduğu görüldü. Nöropati tespit edilen olguların \%33,3'ü kadın, \%66,6'sı erkek idi. Grup-I'deki nöropati tespit edilen ve edilmeyen olgular arasında yaş ortalamaları, cinsiyet, Vücut kütle indeksi değerleri ve laboratuvar ortalamaları arasında istatistiksel olarak anlamlı bir fark bulunmadı ( $p>0,05)$. Nöropati tan kriterlerinin sayı (oranı) açısından subjektif semptomların varlığı $(\mathrm{p}<0,05)$, SWMİ ile duyu kaybının varlığı, diyapazon ve biyoteziyometri ile duyu kaybı, nöropati tespit edilen olgularda edilmeyen olgulara göre istatistiksel olarak anlamlı yüksek bulundu $(\mathrm{p}<0,001)$ (Tablo 3$)$.

Grup-II'de nöropati tespit edilen olguların yaş ortalamasının $67,1 \pm 9,3$ yll, nöropati tespit edilmeyen olguların yaş ortalamasının 66,3 $\pm 9,7$ yıl olduğu görüldü. Nöropati tespit edilen olguların \%61,1'i kadın, \%38,9'u erkek idi. Grup-II'deki nöropati tespit edilen ve edilmeyen olgular arasında yaş ortalamaları, cinsiyet, Vücut kütle indeksi değerleri ve laboratuvar ortalamaları arasında istatistiksel olarak anlamlı bir fark bulunmadı ( $\mathrm{p}>0,05)$. Nöropati tanı kriterlerinin sayı (oranı) açısından subjektif semptomların varlığ $(\mathrm{p}<0,05)$, SWMİ ile duyu kaybının varlığ $(\mathrm{p}<0,001)$, diyapazon $(\mathrm{p}<0,001)$ ve biyoteziyometri $(\mathrm{p}<0,001)$ ile duyu kaybı, nöropati tespit edilen olgularda edilmeyen olgulara göre istatistiksel olarak anlamlı yüksek bulundu. Aşil refleksi kaybı nöropati tespit edilen olguların dördünde görülürken, nöropati tespit edilmeyenlerde aşil refleksi kaybının olmaması istatistiksel olarak anlamlı bulundu $(\mathrm{p}<0,05)$ (Tablo 4).

Grup-III'de nöropati tespit edilen olguların yaş ortalamasinın $62,4 \pm 7,3$ yll, nöropati tespit edilmeyen olguların yaş

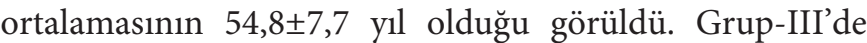
nöropati tespit edilen olguların yaş ortalaması yüksekli-

Tablo 4: Grup-II'ye ait demografik, klinik verilerin, laboratuvar ortalamaları ve nöropati tanı kriterlerinin sayı (oranı) ile istatistiksel değerlendirme sonuçları.

\begin{tabular}{|c|c|c|c|}
\hline \multirow{2}{*}{ Demografik, Klinik, Laboratuvar ve Tanı Kriterleri } & \multicolumn{2}{|c|}{ Grup-II } & \multirow{2}{*}{$p$} \\
\hline & Nöropati var ( $n=18)$ & Nöropati yok $(n=8)$ & \\
\hline Yaş (yıl \pm SS) & $67,1 \pm 9,3$ & $66,3 \pm 9,7$ & 0,717 \\
\hline Cinsiyet (K/E) & $11 / 7$ & $3 / 5$ & 0,274 \\
\hline Vücut kütle indeksi $\left(\mathrm{kg} / \mathrm{m}^{2} \pm \mathrm{SS}\right)$ & $28,6 \pm 7,1$ & $24,95 \pm 4,1$ & 0,255 \\
\hline Hipertansiyon $[\mathrm{n}(\%)]$ & $17(94,0)$ & $6(75,0)$ & 0,160 \\
\hline Hemodiyaliz Süresi (Ay \pm SS) & $42,1 \pm 34,2$ & 41,75 & 0,911 \\
\hline Üre $(\mathrm{mg} / \mathrm{dl} \pm \mathrm{SS})$ & $116,33 \pm 22,5$ & $120 \pm 19,2$ & 0,541 \\
\hline Kreatinin $(\mathrm{mg} / \mathrm{dl} \pm \mathrm{SS})$ & $5,80 \pm 1,7$ & $6,06 \pm 1,6$ & 0,824 \\
\hline Açlik kan şekeri (mg/dl \pm SS) & $186,16 \pm 90,7$ & $172,87 \pm 58,1$ & 0,912 \\
\hline Sodyum $(\mathrm{mg} / \mathrm{dl} \pm \mathrm{SS})$ & $137,94 \pm 3,0$ & $140 \pm 1,7$ & 0,102 \\
\hline Potasyum $(\mathrm{mg} / \mathrm{dl} \pm \mathrm{SS})$ & $4,93 \pm 0,62$ & $4,87 \pm 0,6$ & 0,845 \\
\hline Kalsiyum (mg/dl $\pm \mathrm{SS}$ ) & $8,77 \pm 0,32$ & $9,10 \pm 0,3$ & 0,037 \\
\hline Fosfor $(\mathrm{mg} / \mathrm{dl} \pm \mathrm{SS})$ & $4,42 \pm 0,80$ & $4,85 \pm 1,2$ & 0,420 \\
\hline Parathormon $(\mathrm{pg} / \mathrm{ml} \pm \mathrm{SS})$ & $384,78 \pm 621,1$ & $152,46 \pm 46,2$ & 0,085 \\
\hline Vitamin-B12 (pg/ml) & $891,29 \pm 789,8$ & $374 \pm 282,9$ & 0,160 \\
\hline Folat $(\mathrm{ng} / \mathrm{ml} \pm \mathrm{SS})$ & $12,7 \pm 6,8$ & $11,23 \pm 5,1$ & 0,770 \\
\hline $\left.\mathrm{HbA}_{1 C} \mathrm{C}^{*} \% \pm \mathrm{SS}\right)$ & $7,01 \pm 1,6$ & $7,36 \pm 0,7$ & 0,126 \\
\hline Subjektif semptom var [n(\%)] & $18(100)$ & $4(50,0)$ & 0,030 \\
\hline SWMİ** ile duyu kaybı var [n(\%)] & $17(94,0)$ & $1(13,0)$ & 0,001 \\
\hline Diyapazon duyu yok $[\mathrm{n}(\%)]$ & $18(100)$ & 0 & 0,001 \\
\hline Biyoteziyometri duyu yok [n(\%)] & $16(89,0)$ & 0 & 0,001 \\
\hline Aşil refleksi yok [n(\%)] & $4(22,0)$ & 0 & 0,025 \\
\hline
\end{tabular}

${ }^{\star}$ Glikolize hemoglobin, ${ }^{* *}$ Semmes weinstein monofilament incelemesi 
ği istatistiksel olarak anlamlı bulundu $(\mathrm{p}<0,05)$. Nöropati tespit edilen olguların \%58,3'ü kadın, \%41,7'si erkek idi. Grup-III'deki nöropati tespit edilen ve edilmeyen olgular arasında cinsiyet ve Vücut kütle indeksi değerleri arasında istatistiksel olarak anlamlı bir fark bulunmadı ( $p>0,05)$. Grup-III'deki laboratuvar bulgularından fosforun ortalama değeri nöropati tespit edilenlerde $4,14 \pm 0,2$, edilmeyenlerde
$3,61 \pm 0,4$ bulundu. Grup-III'deki nöropati tespit edilenlerde fosfor yüksekliği anlamlı bulundu $(\mathrm{p}<0,05)$. Nöropati tanı kriterlerinin sayı (oranı) açısından subjektif semptomların varlığ $1(\mathrm{p}<0,05)$, SWMİ ile duyu kaybının varlığı, diyapazon ve biyoteziyometri ile duyu kaybı nöropati tespit edilen olgularda tespit nöropati edilmeyen olgulara göre anlamlı yüksek bulundu ( $\mathrm{p}<0,001)$ (Tablo 5).

Tablo 5: Grup-III’e ait demografik, klinik verilerin, laboratuvar ortalamaları ve nöropati tanı kriterlerinin sayı (oranı) ile istatistiksel değerlendirme sonuçları.

\begin{tabular}{|c|c|c|c|}
\hline \multirow{2}{*}{ Demografik, Klinik, Laboratuvar ve Tanı Kriterleri } & \multicolumn{2}{|c|}{ Grup-III } & \multirow{2}{*}{$p$} \\
\hline & Nöropati var $(n=12)$ & Nöropati yok $(n=38)$ & \\
\hline Yaş (yılıSS) & $62,4 \pm 7,3$ & $54,8 \pm 7,7$ & 0,011 \\
\hline Cinsiyet (K/E) & $7 / 5$ & $23 / 15$ & 0,894 \\
\hline Vücut kütle indeksi $\left(\mathrm{kg} / \mathrm{m}^{2} \pm \mathrm{SS}\right)$ & $30, \pm 3,1$ & $31,1 \pm 5,5$ & 0,683 \\
\hline Hipertansiyon $[\mathrm{n}(\%)]$ & $10(83,0)$ & $24(63)$ & 0,276 \\
\hline Hemodiyaliz Süresi $(\mathrm{Ay} \pm \mathrm{SS})$ & & - & - \\
\hline Üre $(\mathrm{mg} / \mathrm{dl} \pm \mathrm{SS})$ & $31 \pm 10,2$ & $27,8 \pm 6,8$ & 0,369 \\
\hline Kreatinin $(\mathrm{mg} / \mathrm{dl} \pm \mathrm{SS})$ & $0,86 \pm 0,1$ & $0,82 \pm 0,1$ & 0,348 \\
\hline Açlık kan şekeri (mg/dl_SS) & $139,75 \pm 40,1$ & $128,84 \pm 29,2$ & 0,265 \\
\hline Sodyum $(\mathrm{mg} / \mathrm{dl} \pm \mathrm{SS})$ & $141,08 \pm 1,7$ & $141,55 \pm 2$ & 0,498 \\
\hline Potasyum $(\mathrm{mg} / \mathrm{dl} \pm \mathrm{SS})$ & $4,34 \pm 0,4$ & $4,43 \pm 0,3$ & 0,350 \\
\hline Kalsiyum (mg/dl $\pm \mathrm{SS})$ & $9,82 \pm 0,4$ & $9,67 \pm 0,4$ & 0,465 \\
\hline Fosfor $(\mathrm{mg} / \mathrm{dl} \pm \mathrm{SS})$ & $4,14 \pm 0,2$ & $3,61 \pm 0,4$ & 0,001 \\
\hline Parathormon $(\mathrm{pg} / \mathrm{ml} \pm \mathrm{SS})$ & $33,2 \pm 15,7$ & $28,71 \pm 9,8$ & 0,633 \\
\hline Vitamin-B12 (pg/ml) & $328,25 \pm 124,9$ & $336,21 \pm 238,4$ & 0,413 \\
\hline Folat $(\mathrm{ng} / \mathrm{ml} \pm \mathrm{SS})$ & $10,11 \pm 7,2$ & $9,90 \pm 5,1$ & 0,539 \\
\hline $\mathrm{HbAlC}^{*}(\% \pm \mathrm{SS})$ & $7,37 \pm 1,7$ & $7,14 \pm 1,7$ & 0,600 \\
\hline Subjektif semptom var $[\mathrm{n}(\%)]$ & $12(100)$ & $16(42)$ & 0,010 \\
\hline SWMI'** ile duyu kaybı var $[\mathrm{n}(\%)]$ & $6(50,0)$ & $3(8,0)$ & 0,001 \\
\hline Diyapazon duyu yok [n(\%)] & $12(100)$ & $7(18,0)$ & 0,001 \\
\hline Biyoteziyometri duyu yok [n(\%)] & $12(100)$ & 0 & \\
\hline Aşil refleksi yok [n(\%)] & 0 & 0 & \\
\hline
\end{tabular}

${ }^{\star}$ Glikolize hemoglobin, ${ }^{*}$ Semmes Weinstein monofilament incelemesi

Tablo 6: Gruplarda nöropati tanısı konulan olgularda nöropati tanı kriterlerinin oranı ve istatistiksel değerlendirme sonuçları.

\begin{tabular}{lcccccc}
\hline Nöropati Tanı Kriterleri & \multirow{2}{*}{ Grup-I } & Grup-II & Grup-III & $\begin{array}{c}\text { I -II } \\
\boldsymbol{p}\end{array}$ & $\begin{array}{c}\text { I-III } \\
\boldsymbol{p}\end{array}$ & $\begin{array}{c}\text { II-III } \\
\boldsymbol{p}\end{array}$ \\
\hline Subjektif semptom var (\%) & 100 & 100 & 100 & 0,009 & 0,493 & 0,028 \\
\hline SWMİ ile duyu kaybı var (\%) & 83 & 94 & 50 & 0,001 & 0,584 & 0,001 \\
\hline Diyapazon duyu yok (\%) & 100 & 100 & 100 & 0,001 & 0,535 & 0,004 \\
\hline Biyoteziyometri duyu yok (\%) & 83 & 100 & 100 & 0,001 & 0,449 & $\mathbf{0 , 0 0 1}$ \\
\hline Aşil refleksi yok (\%) & 0 & 22 & 0 & & & \\
\hline
\end{tabular}

${ }^{\star}$ Semmes Weinstein monofilament incelemesi 
Nöropati tespit edilen olguların tümünde en az iki tane subjektif semptom görüldüğü bulundu. Grup-I ile Grup-II arasında subjektif semptomların varlı̆̆ açısından istatistiksel olarak anlamlı bir fark bulundu ( $<<0,05)$. Grup-II ile GrupIII arasında subjektif semptomların varlığı açısından istatistiksel olarak anlamlı bir fark bulundu $(\mathrm{p}<0,05)$. SWMİ sonuçlarının istatistiksel karşılaştırılmasında Grup-I ile Grup-III arasinda anlamlı fark bulunmadı $(\mathrm{p}>0,05)$. Grup-II'de duyu kaybı oranı Grup-I ve Grup-III'e göre anlamlı bulundu $(\mathrm{p}<0,001)$. Diyapazon testi sonuçlarının istatistiksel karşılaştırılmasında Grup-I ile Grup-III arasında anlamlı bir fark görülmez iken $(p>0,05)$, diğer gruplar arasinda istatistiksel olarak anlamlı bir fark bulundu $(p<0,05)$. Biyoteziyometri testi sonuçlarının istatistiksel karşılaştırılmasında Grup-I'deki duyu kaybı oranı Grup-II ve Grup-III'e göre anlamlı bulundu $(\mathrm{p}<0,001)$. Aşil refleksi testi sonuçlarının istatistiksel karşılaştırılmasında GrupII'deki aşil refleks kaybı Grup-I ve Grup-III'e göre anlamlı bulundu $(\mathrm{p}<0,05)($ Tablo 6$)$.

Gruplarda nöropati tespit edilenler arasında yapılan istatistiksel değerlendirmede, Grup-I'deki hemodiyaliz olguların 6/35 (\%17)'inde nöropati tespit edilirken Grup-II'deki Tip2 diabetes mellitus tanısı olan hemodiyaliz olguların 18/26 (\%69)'sında, Grup-III'deki kronik böbrek hastalı̆̆ı olmayan tip2 DM olgularının 12/50 (\%24)'ünde nöropati tespit edildi. Grup II'deki nöropati oranı Grup-I ve Grup-III'e göre anlamlı yüksek bulundu $(\mathrm{p}<0,001)$. Grup-I ve Grup-III arasinda anlamlı fark bulunmadı ( $p>0,05)$.

\section{TARTIŞMA}

Periferik nöropati, KBH ve diyabet komplikasyonları arasında en sık görülenidir. Kronik böbrek hastalığı gelişmiş DM hastalarının en az \%50'sinde periferik nöropati varlı̆̆ 1 bildirilmiştir (2). Üremi, kronik böbrek hastalarında nörolojik fonksiyon bozukluklarına sebep olabilir ve bu bozukluklar, hastalarda morbidite ve mortalite oranının artmasında önemli bir etkendir (15). Kronik böbrek hastalı̆ğ olan hastalarda periferik nöropati görülme oranı \%74,6 olarak bildirilmektedir. Son dönem böbrek hastalığ $(\mathrm{SDBH})$ olan yetişkinlerde ayak ülseri ve alt ekstremite amputasyonu riski daha yüksektir. Ayak ülserinin görülme sıklı̆̆ ile ilgili araştırmaların çoğu, diyabetik ayak ülserinin diyabetin başlıca komplikasyonlarından biri olması nedeniyle diyabet hastalarına odaklanmaktadır. Diyabetli ve Evre 4 veya Evre $5 \mathrm{KBH}$ olan hastalarda, yaygin ayak ülserasyonunun diyalizle tedavi edilen hastalarda prediyaliz hastalarından beş kat daha yüksek olduğu bildirilmektedir. Ayrıca diyaliz alan hastalarda diğer alt ekstremite komplikasyonlarının prevalansının (amputasyon, periferik arter hastalığı, önceki ülser ve nöropati) iki kat daha yüksek olduğu rapor edilmiştir.
Ayakta görülen nöropati, ayak ülserleri ve ortaya çıkacak amputasyonlar için önemli bir risk faktörüdür (16-18).

Çalışmamızda, kronik hemodiyaliz tedavisi alan olguların ayaklarında nöropati tespitinde subjektif semptomların değerlendirilmesi, Semmes-Weinstein monofilament incelemesi, diyapazon testi, biyoteziyometre testi ve aşil refleksi değerlendirilmesi kullanıldı. Bu incelemelerden en az iki veya daha fazlası müspet olduğunda nöropati tanısı tespit edildi. Demografik ve klinik özelliklerin gruplar arası istatistiksel olarak karşılaştırılmasında; demografik verilerin gruplar arası değerlendirilmesinde anlamlı fark bulunma$d_{1}(p>0,05)$. Gruplar arasında fark olmamasının sebebi her iki grubunda hemodiyalize giren olgulardan oluşmasıdır. Ortalama laboratuvar değerlerinin gruplar arası istatistiksel olarak karşılaştırılmasında Grup II'deki açlık kan şekeri yüksekliği Grup-I'e göre anlamlıydı. Grup-II'deki açlık kan şekeri yüksekliğinin sebebi grubun DM’lu olgulardan oluşmasidir.

Grup-I ile Grup-III arasında: Grup-I'deki ortalama üre, kreatinin, potasyum, parathormon, Vitamin-B12 yüksekliği ve kalsiyum düşüklüğü anlamlı $(\mathrm{p}<0,001)$ bulundu. GrupI'deki olguların son dönem böbrek hastalığına bağlı hemodiyalize giren olgulardan oluşması nedeniyle bu farklılık görüldü. Grup-II ile Grup-III arasinda; GrupII'deki ortalama üre, keratinin, parathormon yüksekliği ile kalsiyum düşüklüğü anlamlıydı. Ayrıca Grup-II'de anlamlı olarak sodyum düşük ve potasyum yüksekti. GrupII'deki olguların DM'si olan hemodiyalize giren olgulardan oluşması nedeniyle farklılık görüldü.

Çalışmamızda Grup-I ve Grup-II'de nöropati tespit edilen ve edilmeyen olgular arasında ortalama yaş değerlerinde anlamlı bir fark bulunmadi. Grup-III'de ise nöropati tespit edilenlerin yaş ortalaması nöropati tespit edilmeyenlere göre yüksekti. Yapmış olduğumuz literatür taramasında hemodiyaliz olgularında nöropatinin ortaya çıkma yaşı ile ilgili bir araştırmaya ulaşılamadı. Grupların cinsiyet dağılımları açısından değerlendirildiğinde, nöropati tespit edilenlerde cinsiyet açısından anlamlı fark bulunmadı. Nöropati değerlendirilmesinde hemodiyaliz ve diyabet olgularında cinsiyete göre farkları inceleyen çalışma oldukça sınırlıdır. Bu çalışmalara bakıldığında; Aaberg ve ark. 2004-2006 yılları arasında diyabet olgularında nöropatinin cinsiyete göre başlangıcını incelemişler ve nöropatinin cinsiyetler arasında fark bulunmadığını belirtmişlerdir (19). Cinsiyet açısından nöropati oranı arasında fark olmadığından olguların eğitiminde ayak bakımı ve farkındalığın artırılmasında her iki cinsiyet açısından aynı derecede önemli olduğu görülmektedir. 
Gruplarda nöropati tespit edilen olgular ile nöropati tespit edilmeyen olgular açısından gruplarda vücut kütle indeksi, hipertansiyon varlığı, hemodiyaliz süresi ile laboratuvar bulgularından serum, üre, kreatinin, açlık kan şekeri, sodyum, potasyum, kalsiyum, fosfor, parathormon, Vit-B12, folat ve HbA1C değerlerinin ortalama sonuçları arasında anlamlı fark yoktu. Fosfor değeri Grup-III'de nöropati tespit edilenlerde yüksekti. Grup-I ve Grup-II'de nöropati tespit edilenlerle edilmeyenler arasında demografik, klinik ve laboratuvar verileri arasında fark bulunmamasının sebebini olguların tamamının hemodiyaliz olgularından oluşması ve hemodiyaliz tedavisinin etkili olarak yapılmış olmasından kaynaklandığını düşünmekteyiz. Grup-III’deki nöropati tespit edilenlerde yaş ortalamasının yüksek olmasının sebebini gruptaki olguların homojen olmamasindan kaynaklandığını düşünmekteyiz. Grup-III'de nöropatisi olanlarda fosfor yüksekliğinin istatistiksel olarak anlamlı bulunmasına rağmen her iki grupta da fosfor normal laboratuvar sınırları içerisinde bulunmaktadır. Subjektif semptomların varlığı açısından gruplar değerlendirildiğinde; nöropati tespit edilen tüm gruplardaki olguların \%100'ünde her iki ayakta ağrı, uyuşma ya da parestezi yakınması gibi subjektif semptomlar mevcut iken nöropati tespit edilmeyen Grup-I'deki olguların \%24'ünde, Grup-II'deki olguların $\% 50$ 'sinde, Grup-III'de ise \%42'sinde subjektif semptomlar tespit edildi. Baraz ve ark. yaptıkları çalışmaya göre 150 diabetes mellituslu hastanın 57'sinde nöropati tespit edilmiş ve bunların \%38'inde subjektif semptomlar saptanmıştır (20). Bizim yaptığımız çalışmada Grup-III'deki nöropatili olguların tamamında subjektif yakınmalar saptanmıştır. $\mathrm{Bu}$ farklılığın nedeni çalışma gruplarının farklı olması, diyabet süresinin aynı olmamasından ve Grup-III'ün podoloji ünitesine müracaat eden olgu grubu olduğundan kaynaklanmış olabileceğini düşünmekteyiz. Literatürde hemodiyaliz olgularında nöropati tespitinde subjektif semptomları değerlendirmeye alan herhangi bir araştırma bulunmadığından karşılaştırma yapılamamıştır.

Çalışmamızda SWMİ ile duyu kaybı nöropati tespit edilen Grup-I'deki olguların \%83'ünde, Grup-II'deki olguların $\% 94$ 'ünde, Grup-III'deki olguların \%50'sinde duyu kaybı vardı. Grup-I ile Grup-III arasında anlamlı fark görülmezken ( $p>0,05)$, Grup-II'de duyu kaybı oranı Grup-I ve GrupIII'e göre anlamlı yükseklikteydi $(\mathrm{p}<0,001)$. Nia Jones ve ark. tarafindan yapılan ayak ülserleri risk faktörlerinin hemodiyaliz olgularındaki prevelansı çalışmasında nöropati tespit edilen hemodiyaliz alan diyabetsiz grubun $\% 12$ 'sinde, hemodiyaliz alan diyabetli grubun \%37'sinde SWMİ ile duyu kaybı bulunmuştur (21). Yaptığımız çalışmada tüm gruplarda nöropati tespit edilen olgularda SWMI ile duyu kaybı yüksek oranda bulundu. Bunun sebebi çalışma gruplarının ve HD sürelerinin farklı olmasından kaynaklanmış olabileceğini düşündürmektedir.

Nozomu Kamei ve ark. 2005 yllında DM'lu olgularda yapmış oldukları çalışmada SWMİ ile \%60 olguda duyu kaybı olduğunu tespit etmişlerdir (13). Bizim araştırmamızda da DM'lu olguların \%50'sinde SWMİ ile duyu kaybı tespit edildi. Grup-I ve Grup-II'de nöropati tanısında SWMİ ile duyu kaybı yüksek oranda bulundu. Yapmış olduğumuz literatür taramasında hemodiyaliz olgularında SWMİ ile yapılmış araştırmaya rastlanılmadığı için karşılaştırma yapılamadi. Ancak Grup-III'deki diyabetik olgularda SWMİnin nöropati tespitinde duyarlılı̆̆g literatür ile uyumlu bulundu.

Vibrasyon duyusunu ölçmek için biyoteziyometre cihazı ve $128 \mathrm{~Hz}$ diyapazon kullanılmaktadır. Vibrasyon alg1 eşiği periferik nöropatiyi erken dönemde tespit etmek için kullanılan önemli bir kriterdir (22). Bu nedenle biyoteziyometre veya diyapazon ile vibrasyon testi DPN tanısının konulması açısından gerekli olan bir incelemedir ve DPN ile ilişkili çalışmaların çoğunda uygulanmıştır (12, 14, 23-28). Çalışmamızda vibrasyon testlerinden diyapazon testi ile nöropati tespit edilen olguların tamamında duyu kaybı tespit edildi. Biyoteziyometri testi ile nöropati tespit edilen Grup-I'deki olguların \%83'ünde, diğer grupların $\% 100$ 'ünde duyu kaybı tespit edildi.

Araştırmamızda Grup-III'de nöropati tespit olguların $\% 100$ 'ünde biyoteziyometre ve diyapazon ile duyu kaybı tespit edilmiştir. Geetha ve Shanmugasundaram'in 2018'de yaptıkları çalışmaya göre diyabetik nöropati tespitinde biyoteziyometreye ait sonuçlarını $\% 98$ spesifite ve $\% 80$ sensivite olarak bulmuşlardır (22). Bu çalışmanın sonuçları literatürdeki sonuçlar ile uyumlu bulundu.

Çalışmamızda aşil refleksi yokluğu, nöropati tespit edilen Grup-I ve Grup-III'deki olgularda tespit edilmezken GrupII'deki olguların \%22'sinde aşil refleksi alınamadı. Aşil refleksi kaybı nöropatinin ilerlemiş bir bulgusu olup aşil refleksin yokluğu ayak ülser risk artışı ile ilişkilidir (29). Yapılan çalışmalarda da aşil refleksi kaybının düşük oranda olduğu gösterilmiş olup sonuçlarımız literatür ile uyumlu bulundu (13). Derin reflekslerin diyabet süresi, retinopati ve diyabet tedavisi ile ilişkili olduğu saptanmıştır. Diyabet süresi arttıkça derin reflekslerin basamaklı olarak kötüleştiği açıtır ve bu bulgu göreceli olarak ilerlemiş nöropati için bir gösterge durumundadır (13).

Araştırmamızda Grup-I'deki olguların \%17'sinde, GrupII'deki olguların \%69'unda, Grup-III'deki olguların \%24'ünde nöropati tespit edildi. Grup-II'deki nöropati oranı istatistiksel olarak Grup-I ve Grup-III'e göre oldukça yüksek oranda idi. Grup-III'de ayaklarda nöropati oranı klinik olarak yüksek oranda tespit edilmiş olmasına rağmen 
istatistiksel olarak fark anlamlı bulunmadı ( $\mathrm{p}>0.05)$. Yapılan çalışmalarda kronik böbrek hastalığına bağlı nöropati sıklığı \%60-100 arasında değişmektedir (30). Diyabetik olgularda ise yaklaşık \%30 oranında olduğu gösterilmiştir (31). Nia Jones ve ark. diyabeti olmayan 33 hemodiyaliz olgusında buldukları periferik nöropati oranı $\% 18$, diyabeti olan 24 hemodiyaliz olgusinda ise \%50'dir (21). Kaminski ve ark. larının hemodiyaliz hastalarında alt ekstremite amputasyonu ayak ülseri için risk faktörlerini belirledikleri çalışmada grup dağılımlarının bu araştırma ile aynı olduğu, çalışmalarında nöropati oranı Grup-I'de \%25, Grup-II'de \%49, Grup-III'de \%29 olarak tespit ettiklerini bildirmişlerdir (17). Freeman ve ark. da hemodiyaliz tedavisi alan diabetes mellituslu hastalarda nöropati oranını \%36 olarak bulduklarını bildirmişlerdir (32).

Çalışmamızda elde ettiğimiz bulgularla, yapılan çalışmalarda nöropati sıklığının değişik oranlarda bulunmasının en önemli nedenleri çalışma gruplarının farklı olması, hemodiyaliz süresi ve diyabet süresinin farklı olmasından kaynaklandığını düşünmekteyiz. Bu çalışmamızın en önemli sınırlılığ gruplardaki olgu sayısının az olması ve olguların cinsiyet, hemodiyaliz süresi ve etiyolojilerinin homojen olmamasıdır. Çalışmamızın sonuçları, hemodiyaliz olgularında diabetes mellitus olmasa da nöropatinin sık görüldügünü ortaya koymaktadır. Hemodiyalize giren hastalara düzenli podolojik ayak muayenesinin yapılmasının ve nöropati açısından değerlendirilmesinin uygun ve yararlı olacağını düşünmekteyiz.

Teşekküir

Yazarlar, biyoistatistik analizlere desteği için Zonguldak Bülent Ecevit Üniversitesi Tip Fakültesi Biyoistatistik Anabilim Dalı Öğretim Üyesi Dr. Öğr. Üyesi Mustafa Çağatay BÜYÜKUYSAL’a teşekkür ederler.

Etik Kurul Onayı

Zonguldak Bülent Ecevit Üniversitesi Klinik Araştırmalar Etik Kurulu'ndan onay alındı (03.04.2019 tarihli ve 2019/05 Karar No).

\section{Çıkar Çatışması}

Yazarla bu araştırma vemakale için herhangi bir çıkar çatışması olmadığını beyan ederler.

Finansal Destek

Herhangi bir finansal destek alınmamıştır.

Yazarların Makaleye Katkı Beyanı

Fikir ve tasarım; Ülker Özdemir, Selçuk Keser, Literatür tarama, veri toplama, analizi, Yazım; Ülker Özdemir, Selçuk Keser, Taner Bayraktaroğlu, Eleştirel Yaklaşım ve tartışma; Ülker Özdemir, Selçuk Keser, Taner Bayraktaroğlu, Ali Borazan.

Hakem Değerlendirmesi

Yazı hakemlik süreci sonrası yayınlanmaya kabul edilmiştir.

\section{KAYNAKLAR}

1. Tanrıverdi $\mathrm{MH}$, Karadağ A, Hatipoğlu EŞ. Kronik böbrek yetmezliği. Konuralp Tıp Dergisi. 2010;2010(2):27-32.

2. Benbir G, Tursun İ. Kronik böbrek yetmezliği olan ve olmayan diyabetik hastalarda nörofizyolojik değerlendirme. New/Yeni Symposium Journal. 2013;51(2):101-104.

3. Association AD. Clinical practice recommendations 1996. Diabetic neuropathy. American Diabetes Association; 1996. Contract No: 19 (1)

4. Dyck PJ, Davies JL, Litchy WJ, O’brien P. Longitudinal assessment of diabetic polyneuropathy using a composite score in the Rochester Diabetic Neuropathy Study cohort. Neurology. 1997;49(1):229-239.

5. Perkins BA, Bril V. Diabetic neuropathy: A review emphasizing diagnostic methods. Clin Neurophysiol. 2003;114(7):11671175 .

6. Dyck PJ, Larson T, O'Brien P, Velosa J. Patterns of quantitative sensation testing of hypoesthesia and hyperalgesia are predictive of diabetic polyneuropathy: A study of three cohorts. Nerve growth factor study group. Diabetes Care. 2000;23(4):510-517.

7. Lunetta M, Le Moli R, Grasso G, Sangiorgio L. A simplified diagnostic test for ambulatory screening of peripheral diabetic neuropathy. Diabetes Res Clin Pract. 1998;39(3):165-172.

8. Valk G, Grootenhuis P, Van Eijk JTM, Bouter L, Bertelsmann F. Methods for assessing diabetic polyneuropathy: Validity and reproducibility of the measurement of sensory symptom severity and nerve function tests. Diabetes Res Clin Pract. 2000;47(2):87-95.

9. McGill M, Molyneux L, Spencer R, Heng LF, Yue DK. Possible sources of discrepancies in the use of the Semmes-Weinstein monofilament. Impact on prevalence of lnsensate foot and workload requirements. Diabetes Care. 1999;22:598-602.

10. Abbott CA, Carrington AL, Ashe H, Bath S, Every L, Griffiths J, et al. The North-West Diabetes Foot Care Study: Incidence of and risk factors for new diabetic foot ulceration in a community-based patient cohort. Diabet Med. 2002;19(5):377384.

11. Kumar S, Fernando DJS, Veves A, Knowles EA, Young MJ, Boulton AJM. Semmes-Weinstein monofilaments: A simple, effective and inexpensive screening device for identifying diabetic patients at risk of foot ulceration. Diabetes Res Clin Pract. 1991;13(1-2):63-67.

12. Rahman M, Griffin S, Rathmann W, Wareham N. How should peripheral neuropathy be assessed in people with diabetes in primary care? A population-based comparison of four measures. Diabet Med. 2003;20(5):368-374.

13. Kamei N, Yamane K, Nakanishi S, Yamashita Y, Tamura $\mathrm{T}$, Ohshita $\mathrm{K}$, et al. Effectiveness of Semmes-Weinstein monofilament examination for diabetic peripheral neuropathy screening. J Diabetes Complications. 2005;19(1):47-53.

14. Vinik AI, Suwanwalaikorn S, Stansberry KB, Holland MT, McNitt PM, Colen LE. Quantitative measurement of cutaneous perception in diabetic neuropathy. Muscle Nerve. 1995;18(6):574-584. 
15. Doğukan A. Kronik böbrek yetmezliğinde nörolojik bozukluklar. Turkiye Klinikleri Journal of Internal Medical Sciences. 2005;1:28-32.

16. Chen L, Magliano DJ, Zimmet PZ. The worldwide epidemiology of type 2 diabetes mellitus-present and future perspectives. Nat Rev Endocrinol. 2011;8:228-236.

17. Kaminski MR, Raspovic A, McMahon LP, Strippoli GF, Palmer SC, Ruospo M, et al. Risk factors for foot ulceration and lower extremity amputation in adults with end-stage renal disease on dialysis: A systematic review and meta-analysis. Nephrol Dial Transplant. 2015;30(10):1747-1766.

18. Otte J, van Netten JJ, Woittiez AJ. The association of chronic kidney disease and dialysis treatment with foot ulceration and major amputation.J Vasc Surg. 2015;62(2):406-411.

19. Aaberg ML, Burch DM, Hud ZR, Zacharias MP. Gender differences in the onset of diabetic neuropathy. J Diabetes Complications. 2008;22(2):83-87.

20. Baraz S, Zarea K, Shahbazian HB, Latifi SM. Comparison of the accuracy of monofilament testing at various points of feet in peripheral diabetic neuropathy screening. J Diabetes Metab Disord. 2014;13(1):19.

21. Jones NJ, Chess J, Cawley S, Phillips AO, Riley SG. Prevalence of risk factors for foot ulceration in a general haemodialysis population. Int Wound J. 2013;10(6):683-688.

22. Geetha P, Shanmugasundaram P. Assessment of diabetic peripheral neuropathy in type 2 diabetes patients by Biothesiometer. Drug Invention Today. 2019;12(3).

23. Cheng WY, Jiang YD, Chuang LM, Huang CN, Heng LT, Wu HP, Tai TY, Lin BJ. Quantitative sensory testing and risk factors of diabetic sensory neuropathy. J Neurol. 1999;246(5):394398.

24. Cho NH, Shaw JE, Karuranga S, Huang Y, da Rocha Fernandes JD, Ohlrogge AW, et al. IDF Diabetes Atlas: Global estimates of diabetes prevalence for 2017 and projections for 2045 . Diabetes Res Clin Pract. 2018;138:271-281.
25. Dimitrakoudis D, Bril V. Comparison of sensory testing on different toe surfaces: Implications for neuropathy screening. Neurology. 2002;59(4):611-613.

26. Jirkovská A, Bouček P, Wosková V, Bartoš Vr, Skibová J. Identification of patients at risk for diabetic foot: A comparison of standardized noninvasive testing with routine practice at community diabetes clinics. J Diabetes Complications. 2001;15(2):63-68.

27. Olaleye D, Perkins BA, Bril V. Evaluation of three screening tests and a risk assessment model for diagnosing peripheral neuropathy in the diabetes clinic. Diabetes Res Clin Pract. 2001;54(2):115-128.

28. Perkins BA, Olaleye D, Zinman B, Bril V. Simple screening tests for peripheral neuropathy in the diabetes clinic. Diabetes Care. 2001;24(2):250-256.

29. Biçer EK, Çelik S. Diyabetli hastalar için kapsamlı ayak muayenesi ve risk değerlendirmesi. Turkiye Klinikleri Journal of Nursing Sciences. 2016;8(1):62-70.

30. Rizzo MA, Frediani F, Granata A, Ravasi B, Cusi D, Gallieni M. Neurological complications of hemodialysis: State of the art. J Nephrol. 2012;25(2):170-182.

31. Tesfaye S, Stevens LK, Stephenson JM, Fuller JH, Plater M, Ionescu-Tirgoviste $\mathrm{C}$, et al. Prevalence of diabetic peripheral neuropathy and its relation to glycaemic control and potential risk factors: the EURODIAB IDDM Complications Study. Diabetologia. 1996;39(11):1377-1384.

32. Freeman A, May K, Frescos N, Wraight P. Frequency of risk factors for foot ulceration in individuals with chronic kidney disease. Intern Med J. 2008;38(5):314-320. 